\title{
下口唇悪性腫瘍切除後の一再建例
}

\author{
船越 紀子・梅田 敬子・小林 武弘 \\ 板谷 雅恵・羽柴 基之・馬場 駿吉
}

\section{Lower Lip Reconstruction after Malignant Tumor Excision; A Case Report}

Noriko Funakoshi, Keiko Umeda, Takehiro Kobayashi, Masae Itaya, Motoyuki Hashiba and Shunkichi Baba

(Naogoya City University Medical School) lip.

A 86-year-old woman presented with an ulcerated tumor, $19 \times 20 \mathrm{~mm}$, on the lower

The histopathologic examination of the tumor revealed a well-differentiated squamous cell carcinoma.

The primary lesion was resected with an $1.5 \mathrm{~cm}$ margin on each side and the excisional defect was repaired with modified McGregor's fan-shaped flap reported by Nakajima in 1984.

The prognosis was excellent both cosmetically and functionally and there has been no recurrence for 3.5 years postoperatively.

This method is suitable for defects involving over twothirds of the lower lip.

Key words: reconstruction, modified McGregor's fan-shaped flap, lower lip tumor

\section{はじめに}

口唇の悪性腫瘍の多くは扁平上皮癌であり， 治療法としては化学療法, 放射線療法, 外科的 切除があげられる. 外科的切除に際しては腫瘍 が大きくなると再建手術が必要であり，種々の 方法が発表されている，我々は，下口唇扁平上 皮癌の外科的切除後に中島らによる McGregor の fan-shaped flap 変法を用いて一期的再建術 を行い，術後経過良好な症例を得たので，若干 の文献的考察を加えて報告する.

$$
\text { 症例 }
$$

患者 : 86歳, 女性.
主訴: 下口唇部腫瘤.

初診日：昭和62年11月24日.

既往歴，家族歴：特記すべき事なし.

現病歷 : 昭和62年11月初旬, 下口唇の腫瘤に 気付いたが，様子を見ていた。腫瘤は除々に増 大し，腫瘤の一部が自潰したため，近医受診し， 名古屋市立大学耳鼻咽喉科を紹介され初診とな った.

局所所見: 下口唇左側よりに $19 \times 20 \mathrm{~mm}$, 境界比較的明膫, 凹凸不整で表面に潰瘍を形成 する腫瘤を認めた（図 1). 左顎下部に可動性 良好なリンパ節を 1 箅触知した。 
検査所見: 一般血液検查, 検尿では特に異常 を認めなかった. SCC 抗原, CA19-9, CEA と いった腫瘍マーカーにも異常はなかった。

経過：昭和62年11月 24 日当科入院し, 11 月 27 日の腫瘤部生検にて, 扁平上皮癌との病理診断 を得た．組織型は角化傾向は明かでないものの 細胞間橋形成の認められる高分化型であり最大 径 $2 \mathrm{~cm}$ で外科的切除可能と判断したため, 化 学療法, 放射線療法を行わず外科的治療のみと し, 同年12月 7 日下口唇腫瘍摘出術及び下口唇 再建術を施行した.

手術所見：腫瘍周囲より $1.5 \mathrm{~cm}$ 以上の safe-

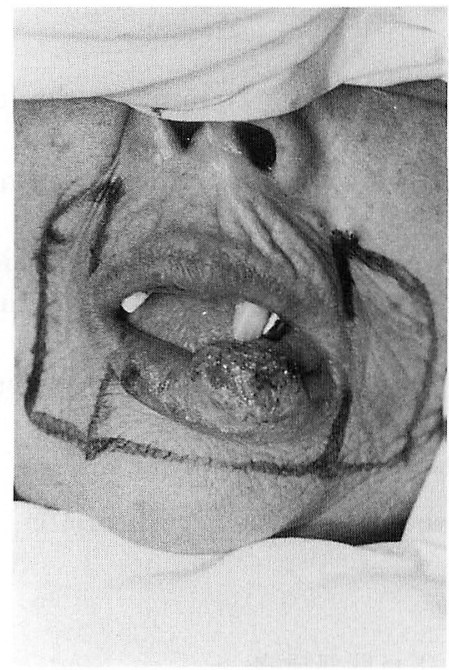

図 1 局所所見

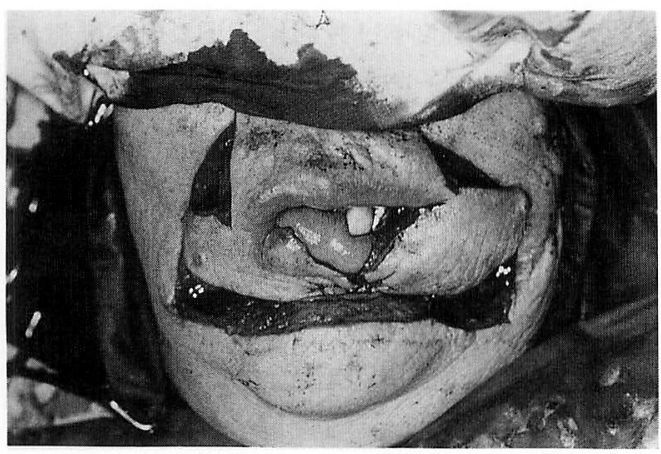

図 2 腫瘍摘出後(鼻唇溝部皮弁を約 $90^{\circ}$ 回転 させて固定） ty margin をとり切除範囲とし, 図 1 の如く皮 弁をデザインした．右口角部をわずかに残し， 下口唇の約 5/6を全層で切除し, 顔面動脈を栄 養血管とする鼻唇溝部の局所皮弁を約 $90^{\circ}$ 回転 させる McGregor の fan-shaped flap 変法によ り一期的に再建を行った（図 2,3 ）。術後 2 週 間目に流動食の経口摂取が可能となり，3 週間 目に退院となった。退院後約 2 力月で義歯の装 着が可能となり， 3 年 6 力月たった現在腫瘍の 再発もなく健在である. 赤唇部の再建手術を行 らと整容的によりよい外観が得られると思われ るが, 患者の同意が得られず施行していない(図

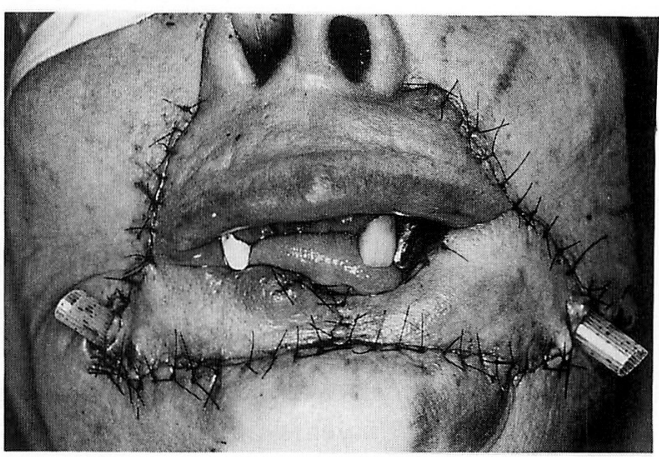

図 3 術直後

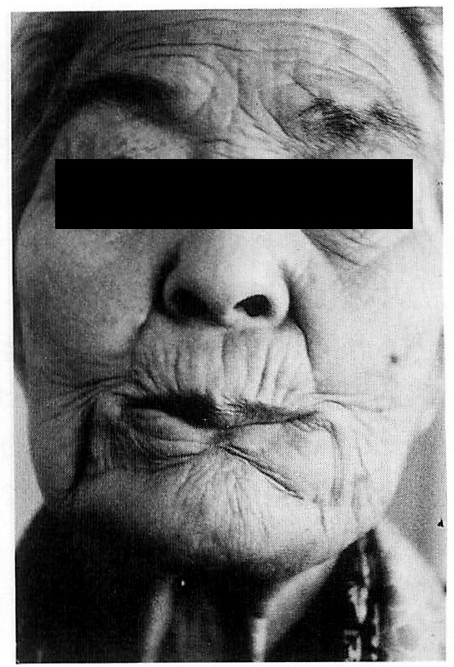

図 4 術後 1 年 
4).

術前に左顎下部に触知したリンパ節は, 術中 病理検査を行ったところ, 転移を認めなかった ので頸部郭清術は施行しなかった。

\section{考案}

口唇癌はパイプタバュ常用者に多発すること が知られている他，長期にわたる強い日光照射 による角化異常を前癌状態として発生する可能 性が言われている1) 7). 性別では男性に多く, 年齢は60歳代にピークをもつ，部位では，下口 唇が圧倒的に多く，組織型では扁平上皮癌がほ とんどで比較的予後のよい高分化型が多い。一 方, 上口唇では扁平上皮癌よりも基底細胞癌の 頻度が高いといわれている7)。上口唇癌は下口 唇癌にくらべ頻度は少ないが，頸部リンパ節転 移が早期に起こりやすく周囲に浸潤しやすいと されている8).

下ロ唇癌のリンパ節転移は，まず，オトガイ 部リンパ節，顎下リンパ節に生じるが，転移率 は一般に低いといわれている8)。組織型にもよ るが下口唇扁平上皮癌の場合，外科的切除にお いて予防的りンパ節郭清は行なわないのが一般 的である. 前田ら9）も，扁平上皮癌については 1 $\mathrm{cm}$ 以上の safety margin をとり，リンパ節は 触知寸る場合のみ郭清を行らとしている，治療 は, 外科的療法に化学療法, 放射線療法を併用 する他, 高齢でこれらが不可能な場合は，レー ザ一切除の他, 凍結療法も良いとされるが，不 十分な凍結はかえって病状の進行を来すことが あり注意しなければならない。

口唇腫瘍では腫瘍切除が充分に行なわれたと 考えられた場合，その機能的，整容的な面より， 即時再建が必要とされる，下口唇の場合，腫瘍 摘出後の欠損の大きさが下口唇全長の $1 / 3$ 以下 であれば，そのまま縫縮可能であるが，1/3を 超える場合には，各種皮弁による再建が必要で ある10)，悪性腫瘍の場合，全層切除がなされる ため，口唇周囲の局所皮弁を用いた再建方法が 多く報告されている．現在用いられる局所皮弁 としては, subcutaneous pedicle flap や tongue flap の他, よく知られているものに Estlander 法11), 逆 Abbe 法12), Gilles の fan flap 法13) が ある（図 5 ). Estlander 法は本来上口唇欠損 に対する下口唇皮弁であるが，この逆を用いて 下口唇欠損を修復することもできる．本法は口 角部が変形するため, 二次的に口角形成術が必 要と考兄られる. Abbe 法 ${ }^{14)}$ は唇裂形成上しば しば用いられる方法であり，下口唇再建として は逆 Abbe 法が用いられる. 逆 Abbe 法の変法 として Stein 法15) や Kazanjian 法16)なども報告 されている。

本症例では, 腫瘍は下口唇の正中やや左側に あり, $1 \mathrm{~cm}$ 以上の safety margin を確保して切 除した場合，右口角部がわずかに残るのみとな る.上口唇を rotation flap として使用する

1. E B t 1 a n d e r 法
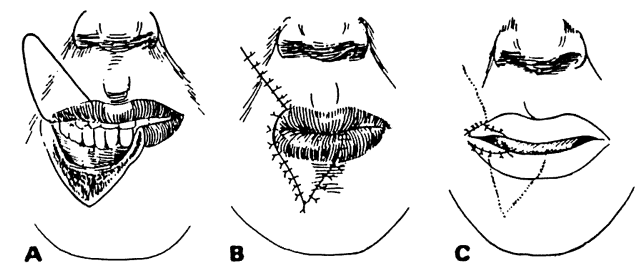

2. 逆 $A b b e$ 法
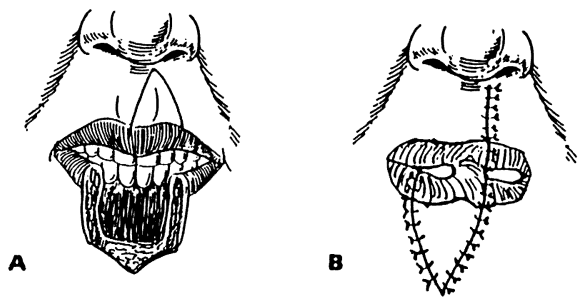

3. G 1111 e s の f a n f l a p 法
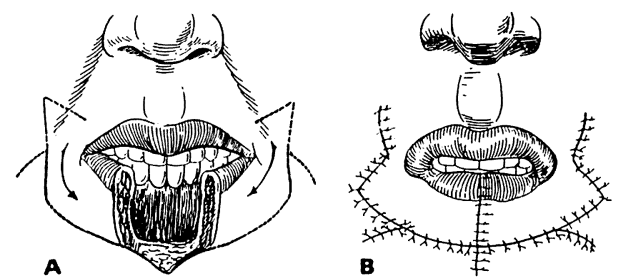

図 5 下口唇悪性腫瘍摘出後の再建法 

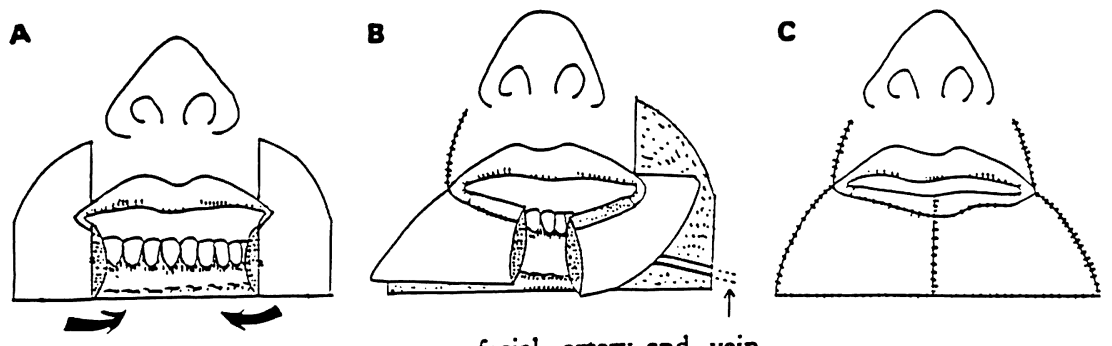

facial artery and vein

図 6 McGregor $の$ fan-shaped flap 変法

(Nakajima T, et al : 1984 ${ }^{19)}$ より転載)

Estlander 法や逆 Abbe 法で本症例の様な切除 範囲を再建するには 2 つ皮弁を用いなければ ならず，いずれも donor としての上口唇の変 形は著明となると考兄られた，上口唇の変形が 比較的少ない方法として Gilles 法, Karapandzic 法17), McGregor 法18) などの fan-shaped flap が報告されている.これらは下口唇の $2 / 3$ 以上の久損に有用である. fan-shaped flap の原 法である Gilles 法は，鼻唇溝部に作成した局所 皮弁を口角部を軸にして rotation flap として， 下口唇欠損部へ移動させる方法である．皮弁の 栄養血管としては上口唇動静脈が口角部に含ま れる．術後の変形としては，口角が丸くなり， ロが少し開きがちになるといら久点がある.

中島ら 19）によって報告された McGregor の fan-shaped flap 変法 (図 6) は, 鼻唇溝部の rotation flap を $90^{\circ}$ 回転させる点は共通してい るが，皮弁の栄養血管として口唇動脈より径の 太い顔面動静脈を温存するため, より安全で確 実な再建法であり, 口角の変形もより少ないの で, 久損の大きい本症例に最も適していると考 えられた. 又, 最近, 寺師ら 20)により上口唇 からの遊離複合移植による一期的再建法が報告 されている.これは, 下口唇を口角側 $10 \mathrm{~mm}$ 程度残してV字形切除した症例に対し, 上口唇 の口角より $5 \mathrm{~mm}$ 離れた部分から正中側へ 10 $\mathrm{mm}$ 幅の遊離複合組織を採取し, 下口唇欠損部 に移動し再建を行う方法である。この方法は, 術後般痕が最小限であり, 手術手技も比較的簡
単で, 下ロ唇全長の $1 / 3 \sim 2 / 3$ の切除後の再建 に試みる方法と思われる。

\section{結語}

今回我々は, 下口唇悪性腫瘍摘出後に, 中島 らによる McGregor の fan-shaped flap 変法を 用いて即時再建を行った症例を報告した。本法 は術後の color match もよく, 機能的, 整容的 にも優れた方法であると思われる．

本論文の要旨は第 55 回日本耳鼻咽喉科学会東海地 方部会連合講演会（名古屋 昭和63年12月）にてロ 演した.

\section{参考文献}

1) Hendricks JC, Mendelson $B C$ and Woods $j E$ : Invasive carcinoma of the lower lip. Surg Clin North Am 57 : 837 844, 1977.

2) Brown RG, Poole MD, Calamel PM, et al : Advanced and recurrent squamous carcinoma of the lower lip. Am J Surg 132 : 492 497, 1976.

3) Wurman LH, Adams GL and Meyerhoff WL : Carcinoma of the lip. Am J Surg $130:$ 470 474, 1975.

4) Lund $\mathrm{C}$, Sogaard H, Elvrond O, et al : Epidermoid carcinoma of the lip. Acta Radiol 14 : 465 474, 1975.

5) Jorgensen K, Elvrond $O$ and Andersen AP : Carcinoma of the lip; a series of 869 cases. Acta Radiol $12: 177 \sim 190,1973$.

6) Yonkers AJ and Yarington CT Jr : Cancer of the lip. Laryngoscope $82: 625 \sim 630,1972$.

7) Bailey BJ : Management of carcinoma of the 
lip. Laryngoscope $87: 250 \sim 260,1977$.

8）広戸幾一郎, 竹田千里 : 臨床耳鼻咽喉科頭頸部 外科全書第 8 巻 B. 95 98頁, 金原出版, 東京, 1985.

9）前田 求：口唇・口腔の悪性腫瘍，上皮内癌な どの治療について. 形成外科 $31: 546 \sim 555$, 1988.

10）吉田哲憲, 大浦武彦: 顔面悪性腫瘍切除後の再 建手術. 手術XXXVIII 1:23～35, 1984.

11) Estlander JA : Eine methode aus Einen Lippe Substanzverluste der Auderen zu Ersetzen (A method of reconstructing loss of substance in one lip from the other lip). The Classic Reprint. Arch Klin Chir 14 : 633, 1872; Plast Reconstr Surg 42 : 361 366, 1968.

12）鬼塚卓弥: 形成外科手術書. 459 463頁, 南江 堂, 東京, 1969 .

13) Gillies $H$ and Millard DR Jr : The principles and art of plastic surgery. pp 507 515, Little Brown and Co, Boston, 1957.

14) Abbe $R:$ A new plastic operation for the relief of deformity due to double harelip. The Classic Reprint. Medical Record 53 : 477, 1898;
Plast Reconstr Surg 42 : 481 483, 1968.

15) Stein SAW : Laenbedannelse udfort paa en ny methode. Hospitals-Meddelelser Copenhagen i, 212, 1848. Br J Plast Surg 33 : 87 91, 1980.

16) Kazanjan $\mathrm{VH}$ and Roopenlan $\mathrm{A}$ : The treatment of lip deformities resulting from electric burns. Am J Surg 88 : 884 890, 1954.

17) Karapandzic $M:$ Reconstruction of lip defects by local arterial flaps. Br J Plast Surg 27 : 93 $\sim 97,1974$.

18) McGregor IA : Reconstruction of the lower lip. Br J Plast Surg 36 : 40 47, 1983.

19) Nakajima $T$, Yoshimura $Y$ and Kami $T$ : Reconstruction of the lower lip with a fanshaped flap based on the facial artery. $\mathrm{Br} J$ Plast Surg 37 : 2 54, 1984.

20）寺師浩人, 倉田荘太朗, 本田朋仁, 他 : 下口唇 悪性腫瘍切除後に打けるわれわれの再建法. 形 成外科 $34: 269 \sim 273,1991$.

$$
\left(\begin{array}{l}
\text { 別刷請求先 : 船越紀子 } \\
\text { T467 名古屋市瑞穂区瑞穂町川澄 } 1 \\
\text { 名古屋市立大学医学部耳鼻咽喉科学教室 }
\end{array}\right)
$$

